\title{
The Lisbon Treaty: De-Constitutionalizing the European Union?*
}

\author{
CHRISTINE REH \\ University College London
}

\begin{abstract}
Calls to ratify the Lisbon Treaty by referendum have been countered with arguments about the Treaty's 'non-constitutional' nature. Against this backdrop, this article asks how much 'constitution' is left in the new document. To answer this question, I assert that little is gained by classifying the Treaty in toto as a 'European constitution' or as the epitome of its failure. Instead, I develop an analytical framework that disaggregates the concept of constitution into its formal, material and symbolic functions, and systematically assess how far Lisbon would strengthen (or weaken) Europe's constitutional quality. The article suggests that, rather than transferring new competences to Brussels or making a constitutional saut qualitatif, Lisbon moderately bolsters the Treaties' formal functions; yet, in contrast to the Constitutional Treaty it adds little in material terms and is a decisive setback symbolically. Calls for ratification by referendum justified by the reform's extent are therefore ill-founded.
\end{abstract}

\section{Introduction}

Over the last five decades both the debate about and the method of constitutionalizing the European Union (EU) have taken very different forms and routes. While post-war Federalists actively propagated a 'European

* I would like to thank Harry Bauer, Richard Bellamy, Maria Cahill, Thomas Christiansen, Thorsten Thiel as well as an anonymous referee for their constructive comments. I am also grateful to the Centre for European Studies at King's College London for giving me the opportunity of presenting the article, and for the detailed feedback I received from Dominik Hanf and John Morijn on an earlier version. 
constitution', the six founding states chose to leave constitutional finalité undefined and opted for functional, step-by-step integration instead. This initial decision to model the European Communities along the lines of an albeit special - international organization opened the door to legal interpretation and systemic evolution. The reform method chosen accordingly was incremental, relying on formal and informal constitutionalization through Treaty reform, jurisprudence and Community politics. Fifty years after its foundation, Europe thus still lacked a constitutional blueprint - and, maybe more importantly, had never gone through an explicit constitutional debate. Only in the face of impending enlargement and a feeling of reform failure after the 2000 Intergovernmental Conference (IGC) did Europe embark on a brief phase of formal, explicit constitutionalization. Starting with the 2001 Laeken Declaration, for about half a decade politicians and the press evoked a 'constitutional moment' (Ackerman, 1991), constitutionalization became a 'buzz-word' (Rittberger and Schimmelfennig, 2006), and '[w]hat is interesting and, indeed, admirable is the speed by which constitutional rhetoric has been normalized and mainstreamed and how quickly the debate has moved from "Does Europe need a constitution?" to "What should be in the new European constitution?"' (Weiler and Wind, 2003, pp. 1f.).

This article is interested in the speed at which the constitutional pendulum swung back in the face of the all too familiar developments - the setting up of the Convention on the Future of Europe (CFE) in 2002, agreement on the Constitutional Treaty (CT) in 2004, ratification in a majority of Member States and rejection in the 2005 French and Dutch referendums. Indeed, the Lisbon Treaty (LT), succeeding the CT and signed by EU Heads of State and Government (HSG) on 13 December 2007, was prepared in an old-style IGC, painstakingly avoiding any reference in either form or substance to a 'European Philadelphia'. There is widespread consensus that the Lisbon Treaty, given its eventual ratification in all 27 Member States, would put an end to both the EU's longest ever reform round and hopes for (and fears of) a 'capital-C Constitution' (Andenas, 2002, p. 103). Yet, once out of the bottle, the constitutional genie proved difficult to put back in, and echoing the brief phase of explicit constitutionalization several Member States, most prominently Ireland and the UK, have asked how much 'constitution' is left in the new text. This and related questions are at the heart of the following discussion. How can a very vocal coalition in the UK call for ratification by referendum, arguing that the latest reform is a qualitative leap in constitutional terms while opponents can claim with equal confidence that the Treaty is decidedly 'non-constitutional'? Why did the Irish government opt for ratification by referendum while Denmark declared a popular vote to be unnecessary? Most generally, how could Europe - in a brief span of time and 
with limited substantive amendments - move from 'ordinary' to 'constitutional' legal foundations and back?

In order to address these questions systematically, this article takes a step back from the political debate in Europe and in Ireland and the UK in particular. The analysis starts from two assumptions. First, I agree with those political and legal analysts who see the CT's content largely preserved, but I argue that looking at form and wording is insufficient when we deal with constitutional law. Second, against the backdrop of Europe's continuous and non-teleological constitutionalization, I assert that little is gained by classifying the Lisbon Treaty in toto as either a 'European constitution' or as the epitome of its failure. Instead, I suggest an analytical framework that disaggregates the concept of constitution into its formal, material and symbolic functions (section I). Drawing on this framework, and assuming that (de-) constitutionalization is likely to remain evolutionary, I analyse how far Lisbon would strengthen (or weaken) the EU's constitutional quality (sections II-IV). At an abstract level, this article thus asks what a constitution can do; analytically, it inquires whether the Lisbon Treaty is likely to do more (or less) than Europe's current constitutional order does, or than the CT would have done. I suggest that, rather than transferring new competences to Brussels or making a constitutional saut qualitatif, the latest reform moderately bolsters the Treaties' formal functions; yet, in contrast to the CT, Lisbon adds little in material terms and is a decisive setback symbolically. Calls for ratification by referendum justified by the reform's extent are therefore ill-founded.

\section{What's in a Constitution? A Framework for Analysis}

The subsequent analysis of the Lisbon Treaty is based on two propositions. First, the constitutionalization of Europe is a continuous, non-teleological process that has conferred - and is conferring - a 'constitutional status on the basic legal framework of the European Union' (Snyder, 2003, pp. 62f.). A similar 'constitutional status' has two main dimensions: the juridification of public authority beyond the nation-state (Scholl, 2006, p. 51), and the transformation of Europe's legal order from a 'relationship binding upon the states $q u a$ states, to an integrated legal order that confers rights and obligations on private parties, and one in which the controls on the exercise of public power are similar in nature to those found in nation states' (Craig, 2001, p. 128). A take on constitutionalization that is 'specifically non-teleological and accepts non-fixity as a way of life' (Shaw, 2003, p. 48) has two repercussions. From a normative perspective, it implies that a capital-C Constitution is deemed 
either unnecessary or is rejected outright (Weiler, 2003); analytically, it redirects attention from the question of whether the EU does - or does not - have a constitution at a particular point in time, to an interest in whether a formal or informal reform has strengthened (or challenged) its constitutional quality on the continuum that is (de-) constitutionalization. This article attempts to assess the latter. Second, in order to arrive at a similar assessment the article focuses on a constitution's legal, political and societal functions. The nonexclusive and non-cumulative criteria suggested in the following are each derived from one such function, and are grouped into a formal, material and symbolic category, respectively. ${ }^{1}$

The analysis starts from Joseph Raz' distinction between 'thin' and 'thick' constitutions (1998). In a 'thin' sense, any law 'that establishes and regulates the main organs of government, their constitution and their powers' would qualify as a constitution (Raz, 1998, p. 153; see also King, 2007, p. 3). When looking at the surface of legal and political discussions about the (non-) existence of a 'European constitution', there seems to be a broad consensus on such a 'thin' constitutional quality. Indeed, if a constitution designates 'the core principles of any given polity' (Eriksen et al., 2004, p. 2), defines and delimits political power and provides normative guidance, the EU's primary law clearly qualifies as such. The Treaties set up institutions of government, define their competences, relationships and decision-making rules, and have been interpreted and applied 'as if they contained the basic constitutional materials of a new political community' (Eriksen et al., 2004, p. 4). In this sense, Europe has indeed 'had a constitution ever since it was constituted' (Andenas, 2002, p. 102) and, even more generally, every international organization with a basic document defining its objectives, competences and organs of governance is constitutionalized (Röben, 2004).

If the 'thin' definition might thus border on the tautological, a constitution's 'thick' features and functions are much more contested and contestable - in the domestic domain, but all the more so at the supranational level (Weiler, 1999b). Raz suggests seven criteria that characterize a 'thick' constitution (1998, pp. 153f.). First, a constitution is constitutive in defining the different branches of government and the powers of their main organs. Including both substantive and procedural norms, a constitution thus sets up a state's political and legal system. Second, a constitution is stable, serving as a 'framework for the political and legal institutions of the country, to be adjusted and amended from time to time, but basically to preserve [...]

\footnotetext{
${ }^{1}$ Similar categorizations have been suggested by Menéndez (2004) and Scholl (2006), who distinguish between formal, material and normative conceptions of the European Constitution, as well as between constitutions' instrumental and symbolic functions.
} 
Table 1: Constitutional Functions - The Analytical Framework

\begin{tabular}{|c|c|c|}
\hline Category & Function & Dimensions \\
\hline \multirow[t]{3}{*}{ Formal } & Codification & Written, superior and justiciable law \\
\hline & Constitution & Setting up and defining a political and legal system \\
\hline & Continuity & $\begin{array}{l}\text { Guaranteeing stability and entrenchment through high } \\
\text { thresholds for change }\end{array}$ \\
\hline Material & $\begin{array}{l}\text { Defining and } \\
\text { institutionalizing } \\
\text { principles of } \\
\text { government }\end{array}$ & $\begin{array}{l}\text { Prominent: separation of powers, fundamental rights, } \\
\text { democratic participation }\end{array}$ \\
\hline Symbolic & $\begin{array}{l}\text { Public recognition } \\
\text { and acceptance }\end{array}$ & $\begin{array}{l}\text { Constitutional provisions are widely known and command } \\
\text { societal consent as a polity's legitimate basis }\end{array}$ \\
\hline
\end{tabular}

continuity in the legal and political structure, and the basic principles that guide its institutions' (Raz, 1998, p. 153). In addition, a constitution is written and superior - enshrined in one or a small number of documents, constitutional law will break conflicting ordinary law. Fifth, constitutions are justiciable with processes foreseen "by which the compatibility of rules of law and of other legal acts with the constitution can be tested, and incompatible rules or legal acts can be declared inapplicable or invalid' (Raz, 1998, p. 153). Furthermore, a constitution is usually entrenched, implying that its amendments have higher thresholds attached than ordinary legislation. Indeed, 'by denominating an issue as "constitutional" we recognize that it is taken off the agenda of normal politics' (Craig, 2001, p. 126). Finally, constitutions rely on a common ideology; including principles of government, such as the separation of powers, fundamental rights and democratic participation. As such, a constitution serves 'not only as a lawyers' law, but as the people's law. Its main provisions are generally known, command general consent, and are held to be the (or part of the) common ideology that governs public life in that country' (Raz, 1998, pp. 153f.). Showing constitutions 'as founded on a contract, an agreement or any other form of social consensus' (Maduro, 2003, p. 81), this aspect especially goes beyond a 'thin' definition.

For the following analysis, Raz' seven criteria are bundled in the three above-mentioned functional categories (see Table 1). With their emphasis on codification and constitution in the narrow sense most features belong to the first, formal category, distinguishing constitutional from ordinary law in form and function. This holds true for Raz' characterization of constitutions as written, superior and justiciable; as setting up and curtailing political and legal order; and as being stable and entrenched (the functions of 'codification', 'constitution' and 'continuity'). Only Raz' last, very encompassing, 
criterion of 'common ideology' goes beyond a similarly formal function: a constitution institutionalizes 'principles of government' as a normative benchmark for legitimate governance (Craig, 2001, pp. 127f.; Jachtenfuchs, 2002; Walker, 2003b, pp. 12f.). The substance suggested by Raz - separation of powers, human rights, democratic participation - are core constitutional standards (Menéndez, 2004, pp. 112ff.), each expressing a different conception of how public power can best be curtailed and of how the treatment of citizens with 'equal concern and respect' can be guaranteed (Bellamy, 2007, p. 1). Finally, when talking of constitutions as commanding 'general consent' Raz refers to their symbolic function (Scholl, 2006, pp. 36ff.). As 'people's law' constitutions are publicly recognized because they generate shared meaning, express a society's ordering principles and grant legitimacy (Menéndez, 2004; Vorländer, 2002). One mechanism to foster public recognition and acceptance is to open and democratize the constitutional process a suggestion repeatedly made for the European context (Habermas, 1995, 2004; see also Closa, 2005; Fossum and Menéndez, 2005).

Focusing on a constitution's functions and disaggregating the concept into a set of non-exclusive, non-cumulative criteria has three advantages. First, such an approach de-couples the discussion about constitutionalism from the discourse about statehood - a pre-condition for any analysis of Europe's sui generis order. Second, the framework allows us to contextualize and compare different substantive and procedural, as well as legal and political dimensions of constitutionalism, rather than to conclude a clear-cut absence or presence of an 'EU constitution'. Comparison can be either diachronic and horizontal - as is the case of this article - or synchronic and vertical, contrasting national and supranational systems, or allocating constitutional functions to different layers of Europe's 'multi-level constitutionalism' (Pernice, 1999). Third, the supranational order is a patchwork of constitutional traditions, and the framework can help us uncover the national origins behind the Treaties (Scholl, 2006).

However, before applying the framework to the Lisbon Treaty in the following sections two caveats are in order. First, any analyst must keep in mind that both the inclusion and weighing of different constitutional criteria will always be normatively contested and that 'real-world' constitutions will display and combine these criteria in different ways. The British uncodified constitution or the varying roles allowed for judicial review are just two prominent examples. Similarly, legal and political theorists have been very outspoken in their rejection of overly legal (or rights-based) variants of constitutionalism (Bellamy, 2007), and in their emphasis on deliberative democratic norms (Menéndez, 2004). Such different conceptions and combinations of constitutional criteria then result in 'different interpretations of the procedure and the agenda of constitution-making' (Menéndez, 2004, 
p. 110) - see, for example, the current political debate, where calls for (or against) ratification by referendum root in the question of whether Lisbon does (or does not) transform the existing legal order into a 'European constitution'. Second, the three constitutional functions are here suggested as heuristic categories and as distinct analytical tools. Such a clear-cut analytical distinction, however, will not conceal the fact that the three functions will strengthen (or weaken) each other in 'real-world' constitutions. Thus, a constitution's formal and material functions not only require public recognition to be fully effective (Menéndez, 2004); they can also reinforce a constitution's symbolic potential. A codified constitutional text, for instance, can foster public recognition, while particular principles of government often underlie a constitution's legitimizing role. Section IV discusses this aspect in more detail.

\section{Beyond a 'Thin' Constitution: The Treaties' Formal Functions}

In its much-quoted and influential Van Gend en Loos judgment, the European Court of Justice (ECJ) decided that 'this Treaty is more than an agreement which merely creates mutual obligations between the contracting states. [...] The Community constitutes a new legal order [...] the subjects of which comprise not only Member States but also their nationals' (Case 26/62 [1963]). Following this judgment and its principle of 'direct effect', Europe's legal community has widely agreed on the existence of a 'thin' supranational constitution. This section analyses whether the Union's legal and political order is 'thicker' in view of the three formal functions of codification, constitution and continuity, and discusses whether and how the Lisbon Treaty is likely to bolster these (see Table 2).

\section{Codification}

Europe's primary law - current and future - fares well in terms of codification, although it poses a number of distinct challenges. The Treaties are a body of written legal text, that has been interpreted by European courts as the Union's constitution. However, with the Treaty Establishing the European Community (TEC), the Treaty on European Union (TEU), a set of binding protocols as well as constitutional principles contained in secondary law it would be inaccurate to speak of one codified document. ${ }^{2}$ Two further

\footnotetext{
${ }^{2}$ When discussing the constitutional status quo as established by the Nice Treaty, I will refer to the TEU and the TEC; when referring to the provisions of the Lisbon Treaty, I will speak of the TEU(L) and the 'Treaty on the Functioning of the European Union' (TFEU), as the TEC would be called post-Lisbon. The Constitutional Treaty would have repealed all other Treaties and is here referred to as CT.
} 
Table 2: The Treaties' Formal Functions Post-Lisbon

\begin{tabular}{|c|c|c|}
\hline Function & Strengthened & Weakened \\
\hline Codification & $\begin{array}{l}\text { Vis-à-vis the Nice status quo } \\
- \text { overall increase in juridification }\end{array}$ & $\begin{array}{l}\text { Vis-à-vis the Nice status quo } \\
\text { - added complexity through } \\
\text { declarations, protocols, opt-outs } \\
\text { - political challenge of supremacy } \\
\text { - Charter Protocol explicitly shields } \\
\text { British and Polish laws from } \\
\text { justiciability } \\
\text { Vis-à-vis the Constitutional Treaty } \\
\text { - Treaties amended, not repealed }\end{array}$ \\
\hline Constitution & $\begin{array}{l}\text { Vis-à-vis the Nice status quo } \\
\text { - (inconsistent) bundling of } \\
\text { constitutive principles in the } \\
\text { TEU(L)'s first Titles } \\
\text { - vertical distribution of powers } \\
\text { clarified: principle of conferral, } \\
\text { Art. } 3 \text { TEU(L) and TFEU Title } \\
\text { on competences } \\
\text { - abolition of pillar structure and } \\
\text { creation of single legal } \\
\text { personality (Art. } 1 \text { TEU (L)) }\end{array}$ & $\begin{array}{l}\text { Vis-à-vis the Constitutional Treaty } \\
\text { - no systematic division of } \\
\text { constitutional and policy provisions } \\
\text { as in the CT's Parts I, II and III }\end{array}$ \\
\hline Continuity & $\begin{array}{l}\text { Vis-à-vis the Nice status quo } \\
\text { - continued 'super-entrenchment' } \\
\text { but simplified revision procedure } \\
\text { (Art. } 48 \text { TEU (L)) }\end{array}$ & $\begin{array}{l}\text { Vis-à-vis the Nice status quo } \\
\text { - increased use of opt-outs and } \\
\text { facilitation of enhanced co-operation } \\
\text { (Title IV TEU (L)) } \\
\text { - inbuilt future reform and passarelle } \\
\text { clauses (Art. } 9 \text { TEU (L)) } \\
\text { - potential territorial instability } \\
\text { through the right to secession (Art. } \\
49 \text { TEU (L)) }\end{array}$ \\
\hline
\end{tabular}

Overall: juridification increased and constitutive function strengthened, but no step towards a single, superior, justiciable document and discontinuity threat through the right to secession

problems stand in the way of approving Raz' first criterion unconditionally. First, key constitutional principles have been developed outside the Treaties and have only been codified step by step - the Court's human rights jurisprudence being a prime example. Second, the Union's constitutional texts are long and complicated, 'lacking in the clarity they would need in order for them to be understood by some and accepted by all' (Piris, 2000, pp. 2, 41). Certainly, the Treaties are nowhere close to a succinct and readable statement of the polity's basic powers and principles. In contrast to Britain's 'unwritten constitution' Europe's Treaties are 'over-codified': they contain 'more in 
some ways and less in others than national constitutions' (Grimm, 1995, p. 289), and their ambiguous language shows that they have been negotiated rather than 'intentionally designed' (Menéndez, 2004, p. 110).

Although the Lisbon Treaty stipulates that '[t]he Union shall replace and succeed the European Community' (Art. 1 TEU (L)), ambiguity and complexity will be aggravated rather than eased in the future. The CT would have repealed the existing Treaties and replaced them with one - if long and detailed - document in four parts: a first part on objectives, competences and institutions was followed by the Charter of Fundamental Rights as well as sections on The Policies and Functioning of the Union and General and Final Provisions. For the IGC 2007, HSG decided that this 'constitutional concept, which consisted in repealing all existing Treaties' was to be 'abandoned' (European Council, 2007a). Indeed, the LT's function is to amend, not to repeal, and it adds rather than reduces complexity through further declarations, opt-outs and protocols. Albeit bundling constitutional principles in Title I TEU(L), it does not do so consistently: the vertical distribution of competences or budgetary principles is part of the detailed TFEU. More will be codified in the LT but codification does not move Europe's legal order any closer to one constitutional text.

Turning to the second dimension, since the ECJ's 1964 Costa v. ENEL judgment, the superiority - or supremacy - of Community law has become an established legal principle (Piris, 2000, p. 8) as well as a pre-condition for citizens' equality under Community law (Menéndez, 2004, p. 117). As such, supremacy - together with direct effect - is at the heart of constitutionalization: the Treaties do not only create relationships between states qua states (as does international law), but confer rights and obligations on third parties and curb public power (as do constitutions). Yet, even if the Community's legal order has moved beyond international law, one can doubt whether it is fully superior. There may be a general tendency for national courts to comply, but 'there is still a challenge to the absolute supremacy of EU law on the part of several national high courts. This is visible either in the description that national constitutionalism's makes of itself or in the dependence of EU law for effectiveness upon national law and national courts' (Maduro, 2003, p. 97; see also Schimmelfennig, 2006). Indeed, the EU relies upon national authorities to apply and implement its law - and thus, ultimately, to ensure its very supremacy (Piris, 2000, p. 17).

The debate about - and the compromise on - the principle of supremacy during Europe's latest reform round has brought this hitherto legal issue into the public-political domain. At first glance, the LT 'clearly confirms the status quo, that is the well-established case-law of the European Court of Justice' (Kurpas, 2007, pp. 3IIf.). Yet, in contrast to the CT, which would have 
explicitly enshrined supremacy (Art. I-6), reacting to political opposition from the UK government and the Dutch voters Lisbon moved the principle to a Declaration Concerning Primacy. Legal scholars have doubted whether constitutional conflict would have been eased with the CT (Kumm, 2005). Yet, the decision by HSG not to codify supremacy in the Treaty's main body, but to move the principle to a non-binding declaration, sends a clear anticonstitutional message: not only 'thinning' the Lisbon text in comparison with the CT such political contestation risks undermining supremacy as a historically grown principle and legal practice.

The picture regarding justiciability is similarly mixed. Although the Union disposes of a well-developed system of judicial review, the Treaties are not unconditionally justiciable. Constitutional conflict occurs and the question of 'who decides who decides' yields different answers from national and Community lawyers (Maduro, 2003, p. 95). Furthermore, the LT entails provisions that explicitly protect national laws from judicial review by the ECJ. The legally binding Protocol on the Application of the Charter of Fundamental Rights, for instance, denies the ECJ as well as national courts the power 'to find that the laws, regulations and administrative provisions, practices or action of Poland or of the United Kingdom are inconsistent with the fundamental rights, freedoms and principles that it reaffirms'. Similarly, even after 2014 - when measures on justice and home affairs (JHA) will fall under the ECJ's jurisdiction - the UK will be able to decide on a case-by-case basis whether to accept the Court's rulings (Brady and Barysch, 2007).

\section{Constitution}

The Union's primary law constitutes the Community, sets its objectives, establishes its institutions, assigns their powers and orders their procedures (Grimm, 1995, p. 289). The Treaties thus closely fit Raz' criterion of 'constitution' - a fit likely to become even closer post-Lisbon.

Most generally, as mentioned above, the TEU(L)'s first Titles bundle most - if not all - of the Union's constitutive provisions. They detail values and objectives (Title I), democratic principles and institutions (Titles II and III), enhanced co-operation and Europe's global role (Titles IV and V) as well as amendment and secession (Title VI). Yet, key constitutional questions - such as the specification of the Union's competences - are found among the detailed policy provisions of the TFEU.

At a horizontal level, the TEU(L) amends Europe's institutions and their powers - granting the European Council institutional status (Art. 9); strengthening the parliamentary component in the election of the Commission President (Art. 9a and d); reducing the College of Commissioners (Art. 9d); 
establishing a permanent President of the European Council (Art. 9b); merging the functions of the High Representative and the Commissioner for External Relations (Art. 9e); and changing the Council's voting system (Art. 9c). Perhaps most significant in constitutional terms, the LT abolishes the pillar structure, thus setting up a single polity with legal personality (Art. 46a).

Concerning the vertical division of powers as well as principles of governance, the new Title I on General Provisions complements subsidiarity and proportionality with the 'principle of conferral', designed to limit the Union's competences (Art. 3 TEU (L)). Albeit still short of a catalogue of competences, a number of new provisions divide vertical powers more clearly. Next to the principle of conferral and the TFEU's Title I on Categories and Areas of Union Competences, Art. 3a TEU(L), for instance, stipulates that the EU shall respect 'national identities' as well as 'essential State functions'. In a similar vein, the Protocol on the Exercise of Shared Competences curtails the supranational level: "when the Union has taken action in a certain area, the scope of this exercise of competence only covers those elements governed by the Union act in question and therefore does not cover the whole area'. The new Treaty also contains the clearest expression yet of the Union's 'lack of independent sovereignty' (Piris, 2000, p. 21), stating in Art. 48 TEU(L) that an IGC can also cut back EU powers.

In sum, the Lisbon reforms bolster the Treaties' constitutive function of setting up and curtailing political and legal power - if in a less systematic way than the CT would have done. At the horizontal level, the new Treaty further defines the organs of government and their powers; at the vertical level, it adds unprecedented clarity, geared at curbing the supranational level.

\section{Continuity}

Turning to the final formal criterion - continuity through entrenchment and stability - the picture is equally mixed. Recalling Raz, entrenchment refers to the particularly high thresholds for constitutional change. Requiring 'dual unanimity' to be changed, the European Treaties have traditionally been 'super-entrenched'. According to Art. 48 TEU (and TEU (L)), HSG need to agree on changes unanimously in an IGC, and all Member States need to ratify the novel provisions according to national constitutional procedures. The Convention had floated the idea of a 'super-qualified' majority in the Council of Ministers to amend policy provisions (Kurpas, 2007, p. 9I), and legal scholars have linked constitutional quality to the possibility of amendment by majority (Besselink, 2008, p. 6). The LT, however, does not fundamentally change the status quo: its 'simplified revision procedure', foreseen next to IGCs to amend Part III TFEU on internal policies, still requires 
unanimity in the European Council and 'shall not increase the competences conferred on the Union' (Art. 48 TEU (L)).

If one defines a constitutional issue as entrenched because it has been taken off the normal political agenda, the supranational case becomes even more complex. Indeed, the 'proper division of power and allocation of functions between the institutions is itself normatively contestable, which has implications for the stability of any European Constitution' (Craig, 2001, p. 139). This is particularly true as the most controversial - and hence unstable - issues have been the ones at the core of Europe's legal-political order: the division of powers between the European institutions, the balance of power among EU Member States, the vertical distribution of competences and decision-rules.

Turning from entrenchment to stability, the Treaties have been stable to the extent that they were concluded for unlimited duration (with the exception of the ECSC that expired in 2002), and (originally) without the right to secession. At the same time, Europe's legal order has been inherently unstable. Formally aiming at functional economic integration, it has been a 'stepping stone [...] [and a] means to reach wider and explicitly political ends' (Menéndez, 2004, p. 117). Since the early 1970s the scope of Community competences has gradually been expanded - mainly through the Court's teleological interpretation and doctrine of 'implied powers' as well as a generous use of Art. $308 \mathrm{TEC}$, allowing the extension of competences without recourse to formal reform (Weiler, 1999a, p. 23). With an additional six major IGCs conducted between 1990 and 2007 alone, the supranational order has indeed been in constant flux and evolution. ${ }^{3}$

The Lisbon Treaty is unlikely to provide more lasting stability - although reform fatigue may well prevent a new IGC from being convened any time soon, and although the HSG 'expect no change in the foreseeable future' (European Council, 2007b). The LT not only preserves Art. 308 TEC, but, by merging the three pillars, theoretically allows its use beyond former Community issues (Kurpas, 2007, p. 2I). Lisbon also contains time lines for future reforms - the new double majority in the Council or the downsizing of the Commission will both enter into force in 2014 (Art. 9c and d TEU (L)) - and allows the European Council to move decision-making from unanimity to qualified majority where the TFEU or Title IV TEU(L) are concerned (Art. 48 TEU (L)). Informal constitutionalization between IGCs is thus likely to

\footnotetext{
${ }^{3}$ Some scholars have considered instability as a normative and pragmatic necessity. A stable constitution may guarantee continuity and, as such, facilitate recognition, the argument runs, but the Treaties as instances of constitutionalization, rather than a fixed constitution, keep substantive and territorial boundaries open, cultivate desirable dialogue and foster constitutional tolerance through the constant recognition of difference (Weiler, 2003).
} 
continue. Finally, beyond the list of issue-specific opt-outs, the Treaty, for the first time in EU history, formalizes a Member State's right to withdraw from the Union (Art. 49 TEU (L)). One might argue that a similar provision is no more than a sign of further juridification or legal clarification. Nevertheless, an institutionalized right to secession introduces territorial flexibility unimaginable in any 'thick' constitution and strongly smacks of international law.

\section{The Material Constitution: Changing Principles of Government}

When judging on the Treaties' supremacy, the ECJ affirmed that certain substantive policy contents are prohibited or mandated by Community law. These policy contents, in turn, became 'the benchmark of constitutionality' (Menéndez, 2004, p. 117), and point to the Treaties' second, material function. This function is closely related to the above-discussed criterion of 'constitution', but whereas the former is 'neutral in moral and political terms' (King, 2007, p. 3), the material constitution entails substantive principles of constitutional government, and thus fills form with content.

The discussion of a constitution's formal functions can be translated relatively easily to the supranational context; discussing the material functions poses numerous challenges. In particular, scholars have debated whether the Treaties should have a material role at all, and whether this role should remain predominantly economic. Closely related are the questions of whether standards devised for nation states can - and should - be applied to European governance, and whether a material constitution is at all possible without statehood. ${ }^{4}$ The two arguments are closely linked: if the Union merely requires an economic constitution for 'market citizens' (Everson, 1995), any aspiration for rights protection beyond the four freedoms and for fully fledged democratic participation is neither necessary nor desirable (Bellamy, 2003).

This article argues that the CT's scope and remit necessitates an analysis of how much material constitution - or normative standard - is left in its successor document. When discussing a constitution's 'thick' functions, section I identified three material standards in particular: the separation of powers, the protection of fundamental rights and democratic participation. The following argues that on all three standards the domestic-supranational gap has widened rather than narrowed post-Lisbon (see Table 3).

\footnotetext{
${ }^{4}$ The article's scope does not allow me to engage with any of these arguments in detail. See Majone (1998) and Moravcsik (2002) for a functional-economic take on the Union and the normative implications of such a view; Weiler (1999b) for the problem of translation and the question of fundamental rights protection; Shaw (1999) and Walker (2003a) for post-national constitutionalism; and Grimm (1995) and Mancini (1998) for two different approaches to statehood, sovereignty and constitutionalism. Ladeur (2008) gives the most recent overview of the debate.
} 
Table 3: The Treaties' Material Functions Post-Lisbon

\begin{tabular}{|c|c|c|}
\hline Principle & Strengthened & Weakened \\
\hline $\begin{array}{l}\text { Separation } \\
\text { of Powers }\end{array}$ & & $\begin{array}{l}\text { Vis-à-vis the Nice status quo } \\
\text { - overall, interlocking rather than } \\
\text { separated powers preserved } \\
\text { - potential horizontal competence } \\
\text { conflict increases the difficulty of } \\
\text { pinpointing executive power and } \\
\text { of allocating responsibility }\end{array}$ \\
\hline $\begin{array}{l}\text { Fundamental } \\
\text { Rights }\end{array}$ & $\begin{array}{l}\text { Vis-à-vis the Nice status quo } \\
\text { - Charter recognized and given } \\
\text { legal status in Art. } 6 \text { TEU(L) }\end{array}$ & $\begin{array}{l}\text { Vis-à-vis the Nice status quo } \\
\text { - Polish and British opt-out } \\
\text { challenges the equality of } \\
\text { European citizens before the law }\end{array}$ \\
\hline $\begin{array}{l}\text { Democratic } \\
\text { Participation }\end{array}$ & $\begin{array}{l}\text { Vis-à-vis the Nice status quo } \\
\text { - Title II TEU(L) Provisions on } \\
\text { Democratic Principles } \\
\text { - citizens' initiative and greater } \\
\text { involvement of national } \\
\text { parliaments (Art. } 8 \text { TEU (L)) }\end{array}$ & $\begin{array}{l}\text { Vis-à-vis the Nice status quo } \\
\text { - simplified revision procedure } \\
\text { further empowers states not } \\
\text { citizens as pouvoir constituant } \\
\text { (Art. } 48 \text { TEU (L)) }\end{array}$ \\
\hline \multicolumn{3}{|c|}{$\begin{array}{l}\text { Overall: differential legal protection undermines the material gain of recognizing the } \\
\text { Charter, and the domestic-territorial dimension of democratic participation is strengthened }\end{array}$} \\
\hline
\end{tabular}

\section{Separation of Powers}

As argued above, Europe's legal and political order goes beyond the usual scope of international law - especially when accounting for the directly elected Parliament, the effective system of judicial review and the possibility of taking decisions by qualified majority. Yet, while most national constitutions subscribe to (at least some) separation of powers, the EU defies this standard. Rather than separated, executive and legislative powers are interlocking and shared between the Commission, the Council of Ministers and the European Parliament (EP):

Institutional balance between the three is the guiding principle of the EC. It is this, rather than some model of separation of powers, which accurately captures the reality of Community decision-making. The precise degree of power which each of these institutions possesses has evolved since the Community's inception. It continues to do so. (Craig, 2001, p. 140)

The LT indeed confirms rather than breaks with this tradition of interlocked competences - a tradition that decreases transparency, makes it difficult to assign responsibility and thus challenges accountability. As demonstrated in section II, the new Treaty further defines the Union's institutions and powers; it also divides vertical competences more clearly, if at the expense of the 
supranational level. At the same time, the LT has new competence conflicts inbuilt, in particular when it comes to executive powers as well as executivelegislative relations. On the one hand, it further parliamentarizes the system, giving the EP budgetary powers and the right to 'elect the President of the Commission' (Art. 9a and d TEU (L)). On the other hand, the LT adds presidential elements by creating yet another executive player: a permanent President of the European Council, elected by the HSG (Art. 9b TEU (L)). Feeding on two different sources of legitimacy - parliamentary and intergovernmental - the Presidents of the Commission and the European Council may well compete about external representation and long-term agenda-setting (Hofmann and Wessels, 2008, p. 11). Post-Lisbon it will thus be even more difficult to pinpoint executive power and to assign responsibility accordingly.

\section{Fundamental Rights}

The separation of powers is one core principle of constitutionalism; fundamental rights protection is another. Both are prominent devices for curbing public power and guaranteeing citizens a zone of non-interference. In Europe, this zone was originally economic, with the 'four freedoms' of goods, persons, services and capital at the heart of the early material constitution (Arts. 23ff., 39ff., 49ff. and 56ff. TEC). The Treaties contained few further rights references, such as non-discrimination on the basis of nationality and equal pay for equal work, both ensuring economic equality. The rationale seemed clear: as long as the Treaties were functionally restricted, a more comprehensive human rights protection seemed unnecessary. Only when the Community started to take binding decisions beyond the purely economic, and when the Court established direct effect and supremacy, did it become 'legally and politically imperative that a way be found to vindicate fundamental rights at the Community level' (Weiler, 1999b, p. 107).

The story of how fundamental rights, next to economic freedoms, have become constitutionalized - reaching from the Court's jurisprudence in cases like Stauder (1969), Internationale Handelsgesellschaft (1970) or Hauer (1979) to the incorporation of human rights in the Maastricht Treaty - is well-known and has been told elsewhere (Stein, 1981; Weiler, 1999b). PostMaastricht, the EU was thus normatively 'thicker' than the previous legal regime, but it still lacked what some consider a core feature of constitutionalism: a catalogue of fundamental rights (Grimm, 1995, p. 287). It is thus unsurprising that the launch of a European 'Bill of Rights' was part (or even the trigger) of the EU's brief phase of explicit constitutionalization. In June 1999, the European Council set up the 'Charter Convention' which prepared a fundamental rights catalogue, building on common constitutional traditions, 
on the European Convention on Human Rights (ECHR) and on ECJ jurisprudence (Dutheil de la Rochère, 2004). In the 2000 IGC, HSG decided against incorporating the Charter into the Treaty, and some of the fiercest political debates in the Convention concerned the Charter's status - viewed as the welcome nucleus of a European Constitution by some, but as a source of legal confusion or as an encroachment on national sovereignty by others.

The CT would have incorporated the Charter as its Title II; the TEU(L) recognizes the 'rights, freedoms and principles set out in the Charter' in Art. 6 and gives it 'the same legal value as the Treaties'. Albeit less visible than the CT's Title II, this recognition could be seen as a leap towards a 'thicker' material constitution. Yet, I would not only caution against such a view but argue that the qualifications added to the Lisbon Treaty in order to make the Charter more palatable for the UK and Poland in particular, undermine rather than strengthen the Treaties' material function. First, the Charter adds little to Europe's rights status quo: the Protocol on the Application of the Charter explicitly states that the document 'reaffirms' existing rights, freedoms and principles and makes them 'more visible', but that it 'does not create new rights'. More importantly, however, Poland and the UK negotiated a de facto opt-out from the Charter. This opt-out undermines a core principle of national constitutionalism: the equality of citizens before the law. Indeed, insulating the two countries from Charter-based judicial review reduces their citizens' protection compared with those in other EU Member States. Diverging from the principle of Member States' equal rights and duties as well as from the unity of EU law, the Charter Protocol also challenges established supranational doctrine (Hofmann and Wessels, 2008, p. 9). The British and Irish intricate system of opt-outs from and opt-ins into JHA - and the Court's jurisdiction - aggravates citizens' differential legal protection along territorial lines. The institutionalized human rights opt-out, falling behind core principles of constitutionalism, national or supranational, thus offsets any 'material gain' through the Charter's recognition.

\section{Democratic Participation}

The previous section mainly talked about rights as 'liberty rights', guaranteeing a zone of non-interference from public power in the field of broadening Community competences. Yet, this 'negative' dimension is but one aspect of fundamental rights, the flipside being political rights of participation, communication and collective will-formation - in short, of democratic inclusion (Habermas, 2001, p. 770; most prominently Bellamy, 2007). Again, both the EP's empowerment and the development of European citizenship have been extensively discussed elsewhere (Bellamy and Warleigh, 2001; Rittberger, 
2005). At the same time, scholars have questioned whether the Treaties can genuinely turn 'subjects' into 'citizens' - a key function of national constitutions. Indeed, while the doctrines of direct effect and supremacy as well as the Union's institutional set-up have distinguished Europe's legal order from international law, as instruments of collective self-organization and self-government the Treaties are wanting (Preuß, 1999, p. 163). First, European citizenship is only derived from national citizenship; second, despite participation and (very limited) scrutiny rights at the supranational level, citizens' main democratic anchor remains the nation state; and, third, states, not citizens, are the pouvoir constitutant of Europe's primary law.

The LT's citizenship provisions (Art. 8 TEU (L)) do not change the first aspect, and the principle of conferral, coupled with Art. 48 TEU(L), underlines the third: albeit institutionalizing the Convention method, the Treaties are still reformed through unanimous consent by HSG, combined with decentralized national ratification. The simplified revision procedure further strengthens the governments' role at the expense of Europe's citizens. Finally, the LT cements the nation-state as democratic anchor - a move certainly welcomed by those scholars who question the possibility of democracy without statehood, or who stress the functionally limited role of the supranational polity. Indeed, Lisbon entails two genuine democratic innovations: the citizens' initiative (Art. 8b TEU (L)), and the greater role given to national parliaments (Art. 8c TEU (L)). Both provisions are based on established territorial principles of democracy: the latter directly, the former indirectly, stipulating that the 'one million citizens' who can call upon the Commission to propose a law must be nationals of 'a significant number of Member States'. This finding resonates with the conclusions drawn in section II, namely that Lisbon bolsters the Treaties' constitutive role and clarifies the division of competences between the national and the supranational level but that it achieves such clarity by decidedly curtailing the European arena. In a similar vein, the latest reform round establishes new norms of democratic participation but anchors them explicitly in the domestic democratic arena.

\section{But No 'Thick' Constitution Yet: The Symbolic Setback}

When categorizing Raz' seven constitutional criteria, a constitution's symbolic function was defined as the 'thickest'. Enabling public recognition and societal consent - in short, legitimacy - this function turns a constitution from 'lawyers' law' into 'people's law'. So far, the article has painted a mixed picture of the Treaties' changing constitutional quality, with their formal and material functions partially resembling and partially defying constitutional 
Table 4: The Treaties' Symbolic Functions Post-Lisbon

\begin{tabular}{|c|c|c|}
\hline Function & Strengthened & Weakened \\
\hline \multirow{2}{*}{$\begin{array}{l}\text { Public } \\
\text { recognition } \\
\text { and societal } \\
\text { consent }\end{array}$} & & $\begin{array}{l}\text { Vis-à-vis the Nice status quo } \\
\text { - explicit political rejection of any constitutional reference } \\
\text { - unawareness/tacit acceptance turned into explicit dissent }\end{array}$ \\
\hline & & $\begin{array}{l}\text { Vis-à-vis the Constitutional Treaty } \\
\text { - deletion of the constitutional symbols of Art. 1-8 CT } \\
\text { - amending rather than repealing the Treaties limits the } \\
\text { symbolic potential of codification } \\
\text { - recognizing rather than incorporating the Charter limits its } \\
\text { symbolic visibility as a Bill of Rights } \\
\text { - overall: 're-de-constitutionalization' of the reform process, } \\
\text { substance and discourse }\end{array}$ \\
\hline
\end{tabular}

Overall, the LT is a symbolic setback vis-à-vis the CT, but the failed attempt at explicit constitutionalization and the rejection, rather than avoidance, of a constitutional register also undermine the incrementally reached and permissively conceded status quo ante.

standards. Yet, post-Lisbon especially a turn from 'black letter' content to 'the social' raises scepticism. Indeed, the Treaties' potential to bolster recognition and to deepen consent has not been enhanced but challenged by Europe's brief phase of explicit constitutionalization. Symbolically, Lisbon is not only a decisive step behind the CT; the choice of an overtly constitutional reform discourse and method, followed by the ratification fiasco in France and the Netherlands, by the subsequent 're-de-constitutionalization' of both language and process and, finally, by the Irish 'no' in June 2008 have lastingly undermined the Treaties' symbolic value. This conclusion is by no means a verdict against the European polity's legitimacy (potential); the following merely argues that in the foreseeable future public recognition and societal consent are unlikely to stem from a symbolic constitution (see Table 4).

\section{Public Recognition and Societal Consent}

Legal scholars and political theorists have long argued that a constitution does not only draw value from its form and substance, but also from the social practice of recognition (Menéndez, 2004). Indeed, constitutions 'are meant to provide a framework for the public life of a country, giving it direction and shape. For this to be achieved, widespread knowledge of the Constitution has to be secured. This requires knowledge not only of the text but of its significance' (Raz, 1998, p. 175). Such recognition need not be as thick as Habermas' 'constitutional patriotism', but it still requires a practice of referring to 'the constitution' as well as an awareness and acceptance of its genesis and content. In short, a constitution is to be known, accepted and sustained. 
At the supranational level and despite the gradual constitutionalization of Europe's legal discourse, there has been 'no single document, or compilation of documents, which social practice refers to as the constitution of the European Union' (Menéndez, 2004, p. 120, italics in the original). Instead, lawyers and legal scholars have invented diverse concepts to capture the nature of the Treaties: there has been talk of a 'constitutional charter' (Case 190/84 [1986]), of an 'intermediate status' (Grimm, 1995), of a 'constitutional system in the making' (Piris, 2000) or of a 'Treaty Establishing a Constitution for Europe', as the CT was officially called. Similarly, in a survey conducted in 2002 at the height of the Convention's activity, only 28 per cent of respondents said they were aware of the constitutional process, but 67 per cent then supported the idea of creating a 'European constitution' (Commission, 2002, 2003). From a purely logical perspective, such calls would have been implausible had a constitution already existed and been backed by a social practice of referring to the document as such (Grimm, 1995, p. 288; Menéndez, 2004, p. 120). The Treaties' form, complexity and technicality, as well as their length and linguistic ambiguity, seem to have hampered rather than fostered recognition and identification. Functionalism not symbolism has traditionally been at the heart of Europe's legal foundation.

If public recognition and (explicit) societal consent have long been left wanting at the supranational level, the latest reform round has dealt them two further blows - first and indirectly, by purging the CT's formal and material reforms of any symbolic value; second and directly, by 're-deconstitutionalizing' the reform discourse and process.

The previous two sections have demonstrated that the Lisbon reforms moderately bolster the Treaties' formal function but add little in material terms. While a similar conclusion could be reached about the LT's predecessor, there is one significant difference: two of the CT's formal and material amendments would have also reinforced the Treaties' symbolic potential; yet, they were stripped of any such symbolism in Lisbon. First, repealing rather than amending the existing Treaties and distinguishing clearly between constitutional and policy provisions, codification under the CT would have played a symbolic as well as a formal role. Contrary to expectations raised when the CFE started its work, the Constitutional Treaty would not have been a readable, pocket-sized constitution. However, the CT would have been one text, whose structure would have made it easier to distil and recognize Europe's ordering principles and validity claims. Second, the TEU(L) gives the Charter of Fundamental Rights legal value; the CT would have incorporated the Charter as its Title II. While this would not have changed the Charter's legal role it would have maximized its symbolic function as a visible 'Bill of Rights'. Such symbolism would have been particularly important given the Charter's limited material 
contribution to Europe's rights status quo; removing it from the LT's main body underlines the new document's anti-symbolic message.

Yet, the Treaties' symbolism was not only weakened indirectly by stripping the CT's formal and material reforms of their potential symbolic function; it was also weakened directly by first pushing and subsequently revoking explicit constitutionalization. Indeed, starting in May 2000 with the famous Humboldt Speech by Germany's then Foreign Minister Joschka Fischer, for a brief while Europe's well-established linguistic ambiguity was transformed into an 'explicitly constitutional register' (Walker, 2006, p. 14, italics in the original). Five years and the CT's ratification fiasco later, Europe saw yet another linguistic u-turn: post-2005 any constitutional reference was painstakingly avoided, and European constitutionalism was openly denied. Among the best illustrations is the European Council's mandate to the IGC 2007, stating simply that the new Treaty 'will not have a constitutional character. The terminology used throughout this document will reflect this change' (European Council, 2007a). Furthermore, any symbolism directly targeted at fostering public recognition - such as the flag, the anthem or the motto included in the CT - was removed. The political tone in combination with the new legal provisions thus conveys a clear and strongly anti-symbolic message: constitution is the " $c$ word' again (Weiler and Wind, 2003, p. 1), and Europe is constituted by an international Treaty. Significant in and of itself, this message becomes even stronger against the backdrop of the explicit interim: pre-2000 constitutional terminology and symbolism were avoided; now they are rejected outright.

\section{The Constitutional Process}

So far, the lack of public recognition and (explicit) societal consent has been linked to the Treaties' form and substance, as well as to Europe's constitutional discourse. The following turns to the way the Treaties have come about. Indeed, if a constitution's recognition can spring from the authority of its authors, from the explicit consent of those concerned or from the law's moral force (Raz, 1998, pp. 157ff.), none of these are given in the case of the EU. The constitutional process has been incremental and evolutionary - based on the Court's jurisprudence, everyday politics and Treaty reform - rather than led by figures commanding symbolic authority. Functionally desirable, this process contributed little to increasing public awareness, recognition or identification, and has been more apt to familiarize the public with national interests and power struggles than to command moral authority. Furthermore, although some national governments have ratified the existing Treaties by referendum, and although all reforms have passed national parliaments, the Union's constitution has never been explicitly endorsed by its citizens. Albeit 
shared with the US Constitution and Germany's Basic Law (Skach, 2005), this feature has consistently been used both by proponents of a constitutional moment (Habermas, 1995, 2004), and by opponents of a 'thick', supranational constitution (Grimm, 1995).

It is in this last respect that the Lisbon Treaty - or, more precisely, the Lisbon process - has most decisively diluted the symbolism of Europe's constitutional order. Indeed, if we subscribe to the argument that a modern and democratic constitution needs to go back 'to an act taken by or at least attributed to the people' (Grimm, 1995, p. 299; see also Menéndez, 2004) the latest reform round was, if anything, a further step away from 'mobilized deliberation' (Ackerman, 1991, p. 7). So far, the Treaties have been set up and changed without explicit popular endorsement in most countries, but they have been ratified by parliaments and, in some Member States, by referendum. It was one aim of the Convention to democratize constitutionalization and to strengthen the Treaties' symbolic function through a 'moment of constitutional import' (Walker, 2006, p. 12). Yet, both politically and symbolically the process backfired: first, the CT was rejected in popular referendums in France and the Netherlands; second, following a 'period of reflection' the constitutional process was decidedly de-democratized. In stark contrast to the 2002-03 Convention process, the Lisbon negotiations thus not only saw the language of international diplomacy return, but also its method. The latest Treaty was agreed in secluded top-political negotiations and was to be ratified in national parliaments - with referendums explicitly excluded in all Member States but Ireland, which is constitutionally obliged to ratify by popular vote and which stalled the ratification process with its 'no' in June 2008.

In sum, previous Treaties have been changed without explicit popular endorsement in most European countries; Lisbon would - eventually - be passed despite the explicit popular rejection of its predecessor as well as an initial Irish 'no'. The widespread popular unawareness of the last decades - or, to put it more positively, the tacit acceptance of the Treaties as 'lawyers' law' - is one matter; the explicit 're-de-constitutionalization' of Europe's reform process and discourse is quite a different development, which will lastingly undermine the symbolic potential of the EU's legal and political order.

\section{Conclusion}

Prior to Europe's interim of explicit constitutionalization hardly any scholar doubted the existence of a 'thin' supranational constitution, yet almost everyone contested its 'thickness' - albeit on different grounds. Indeed, looking back at Raz' constitutional criteria, EU primary law has fulfilled some of his 
standards and defied others - written but not codified in one single document, superior and justiciable but subject to potential constitutional conflict, constitutive of a system of government but only in a functionally restricted domain, stable as concluded for unlimited duration but inherently flexible and evolutionary, displaying a common ideology of policy objectives and governing principles but deficient when it comes to public recognition and explicit societal consent.

Against this backdrop, the article has assessed how much 'constitution' is left in the EU's latest Treaty. To do so, I started from two propositions: first, that the constitutionalization of Europe is a process rather than a fixed state in time; and, second, that to (re-) locate a Treaty on the continuum that is (de-) constitutionalization we need to disaggregate the concept of constitution into its formal, material and symbolic functions. Indeed, scholars and politicians have disagreed about where to place the latest reform on the EU's constitutional continuum - some have argued that Lisbon and the CT make almost identical qualitative leaps while others have claimed that the new Treaty lacks any constitutional quality. Yet, few analysts have looked in any detail at what the Lisbon Treaty can do and why it is likely to do more (or less) than Europe's current constitutional order or the CT.

In a nutshell, after analysing how Lisbon impacts on the formal, material and symbolic functions of Europe's constitutional order, I conclude, first, that the latest reforms further strengthen Europe's 'thin' constitution: juridification increases, if at the expense of the supranational level. Yet, Lisbon weakens Europe's 'thick' constitution vis-à-vis both the Nice status quo and the Constitutional Treaty: it bolsters the Treaties' formal function only moderately, adds little to their material role and decidedly undermines their symbolic potential - both indirectly by stripping the formal and material reforms of their symbolic contribution, and directly by ostentatiously de-constitutionalizing the reform process, substance and discourse.

More specifically, post-Lisbon the Treaties' formal function is strengthened when it comes to codification and constitution in the narrow sense: Lisbon codifies more and more explicitly, it further develops and defines the Union's institutional framework and it clarifies the vertical distribution of competences. At the same time, the Lisbon Treaty is a further step away from a single constitutional document, while the Lisbon process has politically challenged the established legal principles of supremacy and justiciability. Furthermore, where Lisbon bolsters the Treaties' functions to codify and constitute, this is done so as to protect rather than to undermine national sovereignty - in particular through the principle of conferral and the right to secession.

Turning to the Treaties' material functions, Lisbon, on the one hand, amends and adds to Europe's principles of government: the new Treaty 
recognizes the Charter of Fundamental Rights, it contains a Title on democratic provisions and it introduces two new channels of participation: the citizens' initiative and the involvement of national parliaments. On the other hand, the new participation rights are strongly anchored at the national level, and, more importantly, the British and Polish human rights opt-outs undermine equality before the law as a core principle of constitutionalism, thus offsetting any material gain through the Charter's recognition.

Finally, both the outcome and the conduct of the IGC 2007 have dealt the Treaties' symbolic potential a lasting blow. First and indirectly, the CT's formal and material reforms were purged of their symbolism: amending instead of repealing the existing legal order, codification adds further complexity and makes it harder to recognize the Treaties' constitutional function; recognizing rather than incorporating the Charter reduces the text's symbolism as a European 'Bill of Rights'. Second and directly, Lisbon not only abolished the constitutional symbols of the CT; it explicitly de-constitutionalized the reform process and discourse. Pre-2000 constitutional language was avoided, public recognition was minimal and the constitutional process was incremental and built on the (implicit) acceptance of the Treaties as 'lawyers' law'. Following the interim of both explicit constitutionalization and explicit popular dissent, the Treaties are openly denied a symbolic function, and the constitutional process is ostentatiously de-democratized.

In sum, the latest reform round has moved Europe's legal and political order closer to the 'thin' end of Raz' constitutional continuum. This conclusion suggests that calls to ratify the Lisbon Treaty by referendum, justified by an alleged saut qualitatif or competence transfer, are ill-founded. It also explains why the concept of a (European) constitution can still have such different meanings in different contexts.

Correspondence:

Christine Reh

Department of Political Science

University College London

29/30 Tavistock Square, London WC1H 9QU

Tel +44 (0)20 76794772

email c.reh@ucl.ac.uk

\section{References}

Ackerman, B. (1991) We The People (Cambridge, MA: The Belknap Press of Harvard University Press). 
Andenas, M. (2002) 'Can Europe Have a Constitution?' In Melissas, D. and Pernice, I. (eds) Perspectives of the Nice Treaty and the Intergovernmental Conference 2004 (Baden-Baden: Nomos).

Bellamy, R. and A. Warleigh (eds) (2001) Citizenship and Governance in the European Union (London: Continuum).

Bellamy, R. (2003) 'Sovereignty, Post-Sovereignty and Pre-Sovereignty: Three Models of the State, Democracy and Rights Within the EU'. In Walker, N. (ed.) Sovereignty in Transition (Oxford: Hart).

Bellamy, R. (2007) Political Constitutionalism: A Republican Defence of the Constitutionality of Democracy (Cambridge: Cambridge University Press).

Besselink, L.F.M. (2008) 'The Notion and Nature of the European Constitution After the Reform Treaty'. Available at: «http://ssrn.com/abstract=1086189».

Brady, H. and Barysch, K. (2007) 'The CER Guide to the Reform Treaty'. CER Briefing Note, October.

Case 26/62 (1963) 'NV Algemeene Transport- en Expeditie Onderneming van Gend \& Loos v Netherlands Inland Revenue Administration'.

Case 190/84 (1986) 'Parti Ecologiste "Les Verts" v European Parliament'.

Closa, C. (2005) 'Deliberative Constitutional Politics and the Turn Towards a NormsBased Legitimacy of the European Constitution'. European Law Journal, Vol. 11, No. 4, pp. 411-31.

Commission of the European Communities (2002) 'Standard Eurobarometer 57'. Brussels, October.

Commission of the European Communities (2003) 'Flash Eurobarometer: Convention on the future of Europe - wave 2'. Brussels, November.

Craig, P. (2001) 'Constitutions, Constitutionalism, and the European Union'. European Law Journal, Vol. 7, No. 2, pp. 125-50.

Dutheil de la Rochère, J. (2004) 'The EU and the Individual: Fundamental Rights in the Draft Constitutional Treaty'. Common Market Law Review, Vol. 41, No. 2, pp. 345-54.

Eriksen, E.O., Fossum, J.E. and Menéndez, A.J. (2004) 'Introduction: A Constitution in the Making?' In Eriksen, E.O., Fossum, J.E. and Menéndez, A.J. (eds) Developing a Constitution for Europe (London and New York: Routledge).

European Council (2007a) 'Presidency Conclusions: Brussels European Council 21/22 July’. 11177/07 REV1.

European Council (2007b) 'Presidency Conclusions: Brussels European Council 14 December 2007'. 16616/1/07 REV1.

Everson, M. (1995) 'The Legacy of the Market Citizen'. In Shaw, J. and More, G. (eds) New Legal Dynamics of European Union (Oxford: Clarendon).

Fossum, J.E. and Menéndez, A.J. (2005) ‘The Constitution's Gift? A Deliberative Democratic Analysis of Constitution Making in the European Union'. European Law Journal, Vol. 11, No. 4, pp. 380-410.

Grimm, D. (1995) 'Does Europe Need a Constitution?' European Law Journal, Vol. 1, No. 3, pp. 282-302. 
Habermas, J. (1995) 'Remarks on Dieter Grimm's “Does Europe Need a Constitution?" '. European Law Journal, Vol. 1, No. 3, pp. 303-7.

Habermas, J. (2001) 'Constitutional Democracy: A Paradoxical Union of Contradictory Principles'. Political Theory, Vol. 29, No. 6, pp. 766-81.

Habermas, J. (2004) 'Why Europe Needs a Constitution'. In Eriksen, E.O., Fossum, J.E. and Menéndez, A.J. (eds) Developing a Constitution for Europe (London and New York: Routledge).

Hofmann, A. and Wessels, W. (2008) 'Der Vertrag von Lissabon: Eine tragfähige und abschließende Antwort auf konstitutionelle Grundfragen?' Integration, Vol. 31, No. 1, pp. 3-20.

Jachtenfuchs, M. (2002) Die Konstruktion Europas: Verfassungsideen und institutionelle Entwicklung (Baden-Baden: Nomos).

King, A. (2007) The British Constitution (Oxford: Oxford University Press).

Kumm, M. (2005) 'The Jurisprudence of Constitutional Conflict: Constitutional Supremacy in Europe Before and After the Constitutional Treaty'. European Law Journal, Vol. 11, No. 3, pp. 262-307.

Kurpas, S. (2007) 'The Treaty of Lisbon: How Much “Constitution” is Left?' CEPS Policy Brief No. 148, December.

Ladeur, K.-H. (2008) “"We, the European People ...” - Relâche'. European Law Journal, Vol. 14, No. 2, pp. 147-67.

Maduro, M.P. (2003) 'Europe and the Constitution: What if this is as Good as It Gets?' In Weiler, J.H.H. and Wind, M. (eds) European Constitutionalism Beyond the State (Cambridge: Cambridge University Press).

Majone, G. (1998) 'Europe's "Democratic Deficit": The Question of Standards'. European Law Journal, Vol. 4, No. 1, pp. 5-28.

Mancini, G.F. (1998) 'Europe: The Case for Statehood'. European Law Journal, Vol. 4, No. 1, pp. 29-42.

Menéndez, A.J. (2004) 'Three Conceptions of the European Constitution'. In Eriksen, E.O., Fossum, J.E. and Menéndez, A.J. (eds) Developing a Constitution for Europe (London and New York: Routledge).

Moravcsik, A. (2002) 'In Defence of the "Democratic Deficit": Reassessing Legitimacy in the EU'. JCMS, Vol. 40, No. 4, pp. 603-24.

Pernice, I. (1999) 'Multilevel Constitutionalism and the Treaty of Amsterdam: European Constitution-Making Revisited?' Common Market Law Review, Vol. 36, No. 4, pp. 703-50.

Piris, J.-C. (2000) 'Does the European Union Have a Constitution? Does It Need One?' Jean Monnet Working Paper, No. 5.

Preuß, U.K. (1999) 'Auf der Suche nach Europas Verfassung: Europa hat noch keine Verfassung'. Transit: Europäische Revue, Vol. 17, pp. 154-74.

Raz, J. (1998) 'On the Authority and Interpretation of Constitutions: Some Preliminaries'. In Alexander, L. (ed.) Constitutionalism: Philosophical Foundations (Cambridge: Cambridge University Press).

Rittberger, B. (2005) Building Europe's Parliament: Democratic Representation Beyond the Nation State (Oxford: Oxford University Press). 
Rittberger, B. and Schimmelfenning, F. (2006) 'Explaining the Constitutionalization of the European Union'. Journal of European Public Policy, Vol. 13, No. 8, pp. 1148-67.

Röben, V. (2004) 'Constitutionalism of the European Union After the Draft Constitutional Treaty: How Much Hierarchy?' Columbia Journal of European Law, Vol. 10, No. 2, pp. 339-77.

Schimmelfennig, F. (2006) 'Competition and Community: Constitutional Courts, Rhetorical Action, and the Institutionalization of Human Rights in the European Union'. Journal of European Public Policy, Vol. 13, No. 8, pp. 1247-64.

Scholl, B. (2006) Europas symbolische Verfassung: Nationale Verfassungstraditionen und die Konstitutionalisierung der EU (Wiesbaden: VS Verlag für Sozialwissenschaften).

Shaw, J. (1999) 'Postnational Constitutionalism in the European Union'. Journal of European Public Policy, Vol. 6, No. 4, pp. 579-97.

Shaw, J. (2003) 'Process, Responsibility and Inclusion in EU Constitutionalism'. European Law Journal, Vol. 9, No. 1, pp. 45-68.

Skach, C. (2005) 'We, the People? Constitutionalizing the European Union'. JCMS, Vol. 43, No. 1, pp. 149-70.

Snyder, F. (2003) 'The Unfinished Constitution of the European Union: Principles, Processes and Cultures'. In Weiler, J.H.H. and Wind, M. (eds) European Constitutionalism Beyond the State (Cambridge: Cambridge University Press).

Stein, E. (1981) 'Lawyers, Judges and the Making of a Transnational Constitution'. American Journal of Law, Vol. 75, No. 1, pp. 1-27.

Vorländer, H. (2002) 'Integration durch Verfassung?' In Vorländer, H. (ed.) Integration durch Verfassung (Wiesbaden: Westdeutscher Verlag).

Walker, N. (2003a) 'Constitutionalizing Enlargement, Enlarging Constitutionalism'. European Law Journal, Vol. 9, No. 3, pp. 365-85.

Walker, N. (2003b) 'Constitutionalism'. In Axtmann, R. (ed.) Understanding Democratic Politics: An Introduction (London: Sage).

Walker, N. (2006) 'Big “C”' or Small “c”?' European Law Journal, Vol. 12, No. 1, pp. $12-14$.

Weiler, J.H.H. and Wind, M. (2003) 'Introduction: European Constitutionalism Beyond the State'. In Weiler, J.H.H. and Wind, M. (eds) European Constitutionalism Beyond the State (Cambridge: Cambridge University Press).

Weiler, J.H.H. (1999a) 'The Transformation of Europe'. In Weiler, J.H.H. The Constitution of Europe: 'Do the New Clothes Have an Emperor?' and Other Essays on European Integration (Cambridge: Cambridge University Press).

Weiler, J.H.H. (1999b) 'European Democracy and Its Critics: Polity and System'. In Weiler, J.H.H. The Constitution of Europe: 'Do the New Clothes Have an Emperor?' and Other Essays on European Integration (Cambridge: Cambridge University Press).

Weiler, J.H.H. (2003) 'In Defence of the Status Quo: Europe's Constitutional Sonderweg'. In Weiler, J.H.H. and Wind, M. (eds) European Constitutionalism Beyond the State (Cambridge: Cambridge University Press). 